[This is the peer reviewed version of the following article: "Love- According to Simone de Beauvoir" which has been published in final form in A Companion to Simone de Beauvoir (edited by Laura Hengehold and Nancy Bauer), Hooboken, Wiley Blackwell (2017), pp. 160-73. This article may be used for non-commercial purposes in accordance with Wiley Terms and Conditions for Use of Self-Archived Versions.]

\title{
Love - According to Simone de Beauvoir
}

Tove Pettersen, University of Oslo

https://www.stk.uio.no/english/people/aca/tovepe/index.html

Love, a topic among philosophers since Plato, has a prominent role in Simone de Beauvoir's philosophy. According to Beauvoir, love is a universal human experience with the possibility of bringing the highest form of freedom, joy, and fulfillment, as well as grave misery, dependency, and exploitation. Beauvoir discusses various kinds of personal love in her work, including maternal love, lesbian love, friendship, and heterosexual love. In her portrayal of heterosexual love, she draws a distinction between two main types, inauthentic and authentic. Authentic love is "founded on mutual recognition of two liberties," always freely chosen and sustained. It requires that the lovers maintain their individuality, while at the same time acknowledging each other's differences. Inauthentic love is founded on inequality between the sexes, on submission and domination. It prevents both women and men from experiencing freedom, comradeship and the joy of loving. This distinction is, I argue, applicable also to other types of love. Unlike Sartre, Beauvoir believes authentic love is possible. I contrast their respective views. Towards the end, I consider Beauvoir's idea of authentic love in light of her concept of moral freedom, and argue that Beauvoir's authentic love foreshadows feminist notion of "relational autonomy."

\section{Inauthentic Love}

Beauvoir portrays inauthentic love in a highly gendered fashion. "The word 'love' has not at all the same meaning for both sexes," she writes in The Second Sex, "and this is a source of 
the grave misunderstandings that separate them" (TSS 683/LDS II:477). In a patriarchal society, both sexes will experience inauthentic love. Although Beauvoir focuses more on how this phenomenon is manifested by women, a close reading also reveals the obstacles that prevent men from experiencing authentic love (Mundy 2015).

One of the most salient expectations with regard to women's way of expressing love is the demand made for their devotion and self-sacrifice. In Diary of a Philosophy Student (1926-27), the 18-year-old Beauvoir - who at the time believed she would marry her cousin Jacques Champigneulle - is torn between her passion for Jacques and her desire to study. The self-sacrifice she thought would be required of her in marriage seemed impossible to reconcile with studying and living an autonomous life: "[H]e will simply introduce me to his life, but nothing will be changed. As for me, I am gambling all of myself!” $(2006,135)$.

The manifestation and consequences of these gendered expectations of love are analyzed and discussed in The Second Sex. Men, even the most passionate of lovers, Beauvoir points out:

never abandon themselves completely [...] they remain sovereign subjects; the woman they love is merely one value among others; they want to integrate her into their existence, not submerge their entire existence in her. By contrast, love for the woman is a total abdication for the benefit of a master. (TSS 683/LDS II:477-8)

These expectations permeate human life in all its aspects; norms, practices, and interactions. They also inform how women and men perceive themselves, as well as how they judge and what they demand of the opposite sex. In a traditional marriage, for example, women are expected to become part of the man's world by taking his name, joining his religion, following him where he wants to live; "she is annexed to her husband's universe" (TSS 442/LDS II:199).

This situation, and the norms pertaining to it, has a profound influence on the character and behavior of both genders. What is commonly seen as typical for women - such 
as "her convictions, values, wisdom, morality, tastes and behavior - is explained by her situation" (TSS 661/LDS II:451). Beauvoir also expounds the gendered expressions of desires by way of social constructions: "he wants her to be the Other [...] she makes herself object" (TSS 653/LDS II:441). A woman in love is like a "praying mantis" (Beauvoir 2015a, 76). ${ }^{1}$

Women's love construed as a demand for self-sacrifice and devotion does not pertain to romantic love alone. As mothers, daughters, and nurses, the demands are the same. "From childhood woman is repeatedly told she is made to bear children, and the praises of motherhood are sung" (TSS 532/LDS II:299). Motherhood is said to be one of her "sacred rights" and her "ultimate end," and many mothers are guilty of what she calls "masochistic devotion." They turn "themselves into slaves of their offspring," and "they give up all pleasure, all personal life, enabling them to assume the role of victim: and from the sacrifices they derive the right to the deny the child all independence" (TSS, 567-9, 559/LDS II:339-41, 329).

Owing to the all-consuming focus on the other, it is not only the loss of a romantic love that causes a strong reaction in women. The loss of any object of her devotion will lead her to despair. "The mother," Beauvoir writes in Pyrrhus and Cineas (1944), "who contemplates her grown son, like the volunteer nurse who contemplates her cured patients, says with regret, 'You no longer need me!' This regret often takes the form of a reproach" (Beauvoir 2004, 118). Women's ways of expressing love for other people - be it a lover, a child, or a patient - is marked by the affinity for devotion and self-sacrifice.

This act of surrendering resembles religious behavior. The religious woman and the woman in love both long to dedicate and submit themselves to the other. In its most extreme form, inauthentic feminine love finds its clearest expression in the love of the religious mystic for her celestial spouse (TSS 709/LDS II:508). The religious woman who tortures her flesh, "drinking the water in which she had just washed the leper's hands and feet" and 
cleaning the "sick person's vomit with her tongue" (TSS 714-15/LDS II:514-15), expresses her love of Jesus and her neighbor. Apparently, she performs these deeds with pleasure. Such extremes could be pathological, Beauvoir points out, "[b]ut there is this inextricable confusion on many devotees between man and God" (TSS 710/LDS II:510). In behaving like this, the religious woman "tries to connect with the lover using the usual technique of a woman in love: annihilation" (TSS 714/LDS II:514). ${ }^{2}$

This gendered behavior has been explained by asserting that altruism (Schopenhauer 1851), masochism, passivity, and narcissism (Freud 1995[1924]; Deutsch 1944), are naturally occurring traits of the female character. Beauvoir rejects gender essentialism. The way women express love has nothing to do "with a law of nature," Beauvoir declares, whether it is expressed as a tendency to be more other-regarding than men or to enjoy pain inflicted by others: "It is the difference in their situations that is reflected in the conceptions men and women have of love" (TSS 684/LDS II:478). Let us take a closer look at how Beauvoir explains the behavior of women in (inauthentic) love.

Initially, women and men share the same desire for transcendence. This desire plays a prominent role in Beauvoir's philosophy, and she views it as a non-gendered human trait. To Beauvoir, a person is by definition transcendence: "No existent ever renounces his transcendence, especially when he stubbornly disavows it," she says (TSS 469/LDS II:229). It is through transcendence, through the free choice of projects and interaction with other free beings, that individuals can achieve a meaningful and ethical life (Pettersen 2015). In most cultures, however, women's freedom to transcend has been, and still is, limited by her situation. Women usually do not see themselves as their male partners' equal, nor do men typically view them as such. What a woman aspires to, by devoting herself to her beloved, is a union with the superior being, an alliance with the person having the power and possibility to transcend. This brings her, via another, closer to transcendence. Not only does this 
explanation elucidate woman's devotion and self-sacrifice towards her male partner or god, it also sheds light on maternal love. Through her son, the mother can experience transcendence:

The house she did not build, the countries she did not explore, the books she did not read, he will give to her. Through him she will possess the world: but on the condition that she possesses her son. (TSS 560/LDS II:331)

Not so with the daughter. As the daughter is not a member of the "chosen caste," the mother "seeks a double in her. She projects onto her all the ambiguity of her relationship with herself; and when the alterity of this alter ego affirms itself, she feels betrayed" (TSS 561/LDS II:332). Through this explanation, Beauvoir rejects traditional explanations according to which females by nature have submissive character traits. The expression of inauthentic love is a response to women's subordinated position, to being confined to immanence; it is a strategy to cope with oppression. ${ }^{3}$ For many women, love is the "only opportunity" to "enlarge or overturn their universe" (Beauvoir 2015b, 100).

Women's attempt to gain transcendence through another person explains another behavioral tendency of women in love. That is her persistent attempt to get the beloved to dedicate himself completely to her. The woman seeks a timeless union with him, and demands of him that his feelings are absolute and eternal. The reason women so passionately desire to lock the man into a timeless union is precisely why they want to devote themselves to him in the first place. A union with a man represents a way out of the immanence in which she is trapped, by way of an indirect transcendence. This is also why a woman in love is ready to serve and satisfy his needs. By making herself a necessary part of his life, "she will be integrated into his existence, she will be part of his value, his worth, she will be justified" (TSS 691/LDS II:486). This is why the loving woman becomes "a jailer." It is also why the mother clings to her children with a "tyrannical devotion" that obstructs their independence (TSS 560-2/LDS II:331-4). A loving woman wants to imprison a free being, bolt free 
existence onto her immanence, so that her contact with transcendence will be secured. Of course, this is destined to fail; a free being cannot be owned (TSS 698/LDS II:495).

Her desire to achieve complete union with the loved one through devotion, implies that the woman "lets her own world founder in contingence; she lives in his universe" writes Beauvoir (TSS 693/LDS II:489). Herein lies one of the many paradoxes of inauthentic romantic love. The woman in love seeks the approval of her being as something irreplaceable, a confirmation that her life has a unique meaning. Nevertheless, in order to gain this approval, she eradicates her individuality and aspires to become one with her partner, eliminating as a result the differences between the two. This is what eventually kills the love between them. On Beauvoir's view, it is precisely the uniqueness of the other that draws the two together in the first place, and also what can prolong and uphold the attraction (Beauvoir 2015a, 79; 2015b, 101). However, in her attempt to become one with the beloved, she makes herself part of the other's facticity. The sexual act is "no longer an intersubjective experience where each goes beyond himself, but rather a kind of mutual masturbation" (TSS 467/LDS II:226-7). The sexual relationship becomes inauthentic and "bestial" (TSS 458/LDS II:216).

Not only does her attempt to become one destroy their love, such union is also unethical in Beauvoir's philosophy. A woman who devotes herself completely to her partner does not take responsibility for herself and her own life - as Beauvoir's existentialist ethics requires (Pettersen 2007, 2015). Women's self-denial and subjugation are not entirely positive from a male perspective either. Since the woman, on entering into the relationship, adores and idolizes him, she does not see his vulnerability or the threat to his projects. She is not his companion, and he is not allowed to fail (TSS 695/LDS II:491-2). But eventually, when she discovers his fallibility, she begins to despise him. Everything he does from now on is wrong: "The chevalier who embarks on new feats of prowess offends his lady; but she 
scorns him if he stays seated at her feet" (TSS 698/LDS II:698). This is another of the painful paradoxes of inauthentic love: a captive god is shorn of his divinity (TSS 698/LDS II:495). Although privileged, neither can the man in an inauthentic romantic relationship realize his full human potential as a free being without an equal partner. He will not be "healed of his egoistical pride," nor experience self-negation and devotion (Beauvoir 2015a, 78), nor the benefits of comradeship. In addition, if his masculine identity and dominant position are dependent on women's subordination, he is not free (Gunnarsson 2013, 165; Mundy 2015). If the man in love is governed by conventional masculine ideals, he too lives an inauthentic and unethical life, unable to experience authentic love.

The lack of equality between women and men also manifests itself in the way jealousy is experienced and expressed. Men are jealous simply because of their "will to exclusive power," writes Beauvoir. A sleeping woman does not represent a threat to him. She belongs to nobody" (TSS 696-7/LDS II:493). But to women, even a sleeping man is a threat. Why? Because when he sleeps, he doesn't think about her (TSS 698/LDS II:493-4). Whatever he looks at that is not her, she experiences as threatening:

[A]s soon as he looks at something other than her, he frustrates her; everything he sees, he steals from her; far from him, she is dispossessed both of herself and of the world; even seated at her side, reading, writing, he abandons her, he betrays her. (TSS 696/LDS II:493)

The woman who tries to preserve her own transcendence by surrendering to a man, is witnessing her transcendence not being brought out into the world every time he is not aware of her (TSS 698/LDS II:495). As he is her link to the world, she sinks into immanence without his attention.

Beauvoir's grim description of inauthentic love is essentially a portrayal of how heterosexual love manifests itself on patriarchal terms of human interaction. It is described in Beauvoir's philosophy as a distorted, degenerate, and unethical form of love, doomed to fail. Traditional marriages commonly epitomize inauthentic love since the relation between the 
spouses in such relationships is based on domination as opposed to companionship, and because the other is not recognized as an irreplaceable, unique being. Additionally, if the marriage is not freely chosen and continually renewed, this further contributes to the marriage's unethical arrangement. Consequently, adultery can sometimes manifest authentic love and moral freedom.

Lesbian love can take many forms and also be inauthentic, but nevertheless holds a greater potential for overcoming the patriarchal structures entrenched in traditional heterosexual love. Two women in love will not so easily be trapped in conventional femininity. In a culture where femininity "means mutilation" (TSS 421/LDS II:175), lesbian love allows women to "free themselves of the chains attached to femininity" (TSS 424/LDS II:178), to experience love without becoming the Other. This is precisely why it provokes; lesbian love acknowledges women as sovereign subjects and consequently challenges the gender hierarchy: “As an 'erotic perversion' feminine homosexuality elicits smiles; but inasmuch as it implies a way of life, it provokes scorn or scandal” (TSS 434/LDS II:189).

However, inauthentic love is not the only form of love possible between women and men. Authentic love between the sexes is achievable - but only when they acknowledge each other as equals and as unique. Hence, while inauthentic love can be described as patriarchal, authentic love can be labeled post-patriarchal since sexism must be eradicated for authentic relationships to flourish.

\section{Authentic Love}

Authentic love contains two components that are missing in the inauthentic version. First, there is mutual recognition of each other's differences; second there is the mutual recognition of each other's equality. Aspiring to both difference and equality might sound like a contradiction, but it is actually in harmony with Beauvoir's existentialist ontology, which 
sees ambiguity as part of the human condition (Beauvoir 1976, 7-8). "Human nature is only worth its salt when it brings together these two natures," writes Beauvoir, and "love given and love received" is the "most powerful aid in bringing this paradoxical synthesis" (2015a, 77). Let us inspect these two significant features of authentic love.

\subsection{Recognition of differences}

"An authentic love," writes Beauvoir, "should take on the other's contingence, that is, his lacks, limitations, and originary gratuitousness; it would claim to be not a salvation but an inter-human relation" (TSS 694/LDS II:491). It is vital to perceive love as a human interaction. If the individuality of one of the partners - usually the woman - is curbed, if she is regarded as a mere extension of her male partner, she cannot be loved for her uniqueness. Sexuality in relationships where the individual differences have been eradicated is unethical, she writes. This is because physical love in such relationships is not justified by individuals, but by God or society, and then "the relationship of the two partners is no more than a bestial one" (TSS 458/LDS II:216). Consequently, "an authentically moral erotic life" is possible only when the other is recognized as a unique individual. Here we see exactly what differentiates authentic and inauthentic physical love. Authentic physical love is based on the lovers' full consent and on their acknowledgment of each other's uniqueness. Inauthentic physical love - typical of traditional marriage - gives sex "an instrumental, thus degrading character" as they are doomed to know each other in their generality, that is, as bodies, not as persons (TSS 465/LDS II:225).

Failing to recognize the individual differences not only makes sexuality unethical, it is, according to Beauvoir, also the biggest turn-off in a romantic relationship. The reason is that "[e]roticism is a movement towards the Other, and this is its essential character; but within the couple, spouses become, for each other, the Same; no exchange is possible between them anymore, no giving, no conquest" (TSS 467/LDS II:226). It is the lack of 
individuality, the absence of mutual recognition of each other's uniqueness, which, according to Beauvoir, kills the traditional marriage. Sexuality, romance, and love are drowned in boredom when one of the partner's perspectives and opinions are mere repetitions of the other's. Authentic love therefore requires both maintaining their individuality and selfrespect, and acknowledging the differences between them.

\subsection{Recognition of equality}

A necessary but insufficient condition to achieve true love, is for the individuals to acknowledge their differences. Additionally, they must also recognize each other as equals. To recognize the other as an equal is to acknowledge the other as a free being. Only then can love for the woman, as for the man, become "the source of life and not a mortal danger" (TSS 708/LDS II:708):

Authentic love must be founded on reciprocal recognition of two freedoms; each lover would then experience himself as himself and as the other; neither would abdicate transcendence, they would not mutilate themselves; together they would reveal values and ends in the world. (TSS 706/LDS II:505)

In an authentic love relationship, each party must choose to respect their own freedom as well as that of the other, Beauvoir emphasizes. By respecting the other's freedom, one refrains from dominating, controlling, and suppressing the other. But equally important; by respecting one's own freedom, one rejects a submissive role and refrains from seeking to devote oneself to another - as is the case in inauthentic love. For a woman to achieve authentic love, she must essentially exist as pour-soi-for-herself - as men do. This means that she must be financially independent, "project herself toward her own ends," and transcend herself towards the world without using a man as an agent (TSS 707/LDS II:506).

Authentic love is (ideally) non-possessive and non-submissive. Consequently, the differences between the parties, such as gender, race, class, and age, will not allow one to 
enjoy, unjustifiably, more freedom, power, and possibilities than the other - or to renounce one's own freedom. Moreover, authentic love is always freely chosen, sustained, and voluntarily renewed. Free, renewed, and reciprocal recognition is a prominent characteristic of authentic love, and is exactly what makes this, rather than inauthentic love, ethical. Authentic love expresses moral freedom. Or, in the words of Nancy Bauer:

genuine love is an expression of the highest of moral laws: when I love another person genuinely I both exercise my existential freedom and evince the highest respect for the freedom of other, on which, I understand, my own freedom rests. (Bauer 2001, 164-5)

Regardless of gender, race, and class, authentic love requires a reciprocated recognition of both differences and equality. But is this applicable to maternal love? As the mother-child relationship is asymmetrical, a full-blown reciprocity cannot take place. Nevertheless, maternal love can also be authentic. First, "since maternal love has nothing natural about it" "the relation of parents to children, like that of the spouse, must be freely chosen" (TSS 5667/LDS II:338-9). Second, the mother must respect her own freedom, as well as her child's. Consequently, she will not justify her existence through motherhood alone, but must also pursue other freely chosen projects. Nor will she hamper the independence of her children, instead aiming to create a situation from which "the child's freedom can transcend" (TSS 568/LDS II:340).

It would obviously be better for the child if his mother were a complete person and not a mutilated one, a woman who finds in her work and her relations with the group a selfaccomplishment she could not attain through his tyranny; and it would be preferable also for the child to be left infinitely less to his parents than he is now, that his studies and amusements take place with other children under the control of adults whose links with him are only impersonal and dispassionate (TSS 568/LDS II:340)

Obviously, authentic love requires more than mutual recognition - which Beauvoir also terms moral freedom. Whether or not the agents are capable of recognizing the freedom of self and others, is also dependent on the situation. The social and economic circumstances shape 
people's understanding of love and impact if and how their desires can be carried out. If, for example, birth control and abortion are inaccessible, if same-sex relationships are forbidden, if dominant cultural myths depict women as submissive and men as sexually aggressive, love will be deformed. In addition to reciprocated recognition, authentic love also requires concrete freedom. Concrete freedom refers to the measure of freedom people possess in a particular situation. Whether we enjoy political rights, have sufficient material resources to exercise our freedom, or live instead in "bad faith," these situational attributes affect the agent's capacity to make free choices and act thereon also when it comes to love.

\section{Beauvoir's View on Love Contrasted with Sartre's}

The publication of Beauvoir's Diary has been an invaluable contribution to Beauvoir scholarship, in particular with regard to the debate about the influence of Jean-Paul Sartre, and the exchange of ideas between them. What Diary demonstrates is that central ideas of her later philosophy are prefigured in these very early writings - several years before she even met Sartre. A close reading of Beauvoir's works shows that the position she developed on topics related to love departs distinctly from Sartre's.

As already mentioned, Beauvoir is indeed conscious in Diary of the demand that women sacrifice their own interests and autonomy on entering into a traditional heterosexual relationship. In addition to these early reflections of what she would later term inauthentic love, she also foreshadows the type of love she would term authentic. The love she aspires to in Diary, "is not a subordination, and leaves the one who loves the care of seeking his own directions, of leading an independent, individual life" (Beauvoir 2006, 76). The idea that authentic love must contain the apparently ambiguous element of difference and equality is expressed in her ideas about a future partner for whom she will not have to give up her own life: "One must love him in this very difference without seeing it as an inferiority, which 
would be unjust for oneself" $(2006,77)$. Since the two individuals in love are separate and different, they cannot merge and be one - even though they might reach out for it. It would be "absurd," because the "union of the souls" is "impossible" $(2006,76)$. Nevertheless, even if a complete union cannot be achieved, the two lovers need not live their lives completely separated. Beauvoir seeks a middle way between being merged and being divided: the lovers can live parallel lives. Envisaging a marriage that differs from the traditional one, the 18year-old Beauvoir writes: "They are going to continue their life, side by side, but outwardly far from one another, and this, whatever their love may be, if they evolve in parallel, is perfect" $(2006,78)$. This echoes Beauvoir's later portrayal of authentic love, as, for instance, in The Ethics of Ambiguity, where she writes: "To love him genuinely is to love him in his otherness and in that freedom by which he escapes" $(1976,67)$. It also resembles The Second Sex's claim that love must be "founded on the recognition of two freedoms" (TSS 520/LDS II:286), as well as her assertion in “It's about time women put on a new face on love" (1950), that "the miracle achieved by love alone" will only happen if one can "cherish in the individual what gives him his difference and still accord him the universal rights that are every human being's" $(2015 \mathrm{a}, 77)$. Throughout Beauvoir's entire output "it is this love that is the most complete relationship possible with another person" (2015a, 78).

According to what Sartre writes in Being and Nothingness (1943), such love is not possible. ${ }^{4}$ There are two fundamental attitudes toward the other, he contends. One is "to transcend the Other's transcendence," the other is "to incorporate that transcendence within me without removing from it its character as transcendence" (Sartre 2005, 385). The two attitudes conflict. In fact, as he himself claims, "each attempt is the death of the other" (2005, 385). For Sartre, our freedom as individuals is at risk whenever we encounter others, including - or especially - others with whom we form a romantic relationship. The two attitudes toward concrete others imply that love takes place within a subject-object 
relationship involving an unavoidable battle over who is to occupy the role of object or of subject. The reason one jeopardizes one's freedom in relations with others is that one has to deal, intellectually, with the structure of being-for-the-other - which, in a romantic relationship, means one of the two has to become an object.

When two are in love they will attempt to adjust to the beloved's look, by trying to look at the beloved the way the beloved looks at them. In doing so, people in love surrender their uniqueness and renounce their freedom. They will try to seduce the beloved to love them as something they are not - which, to Sartre, is an act of bad faith. If the one does not submit, and both look at each other, "the struggle of two freedoms confronted as freedoms" will be out in the open (Sartre 2005, 401). There will be a battle between the two freedoms until it is established which is the subject and which the object in this relationship. For Sartre, there is no way of transcending the subject-object relationship; either you lose your own freedom or you deny the other theirs. In fact, the problem of being-for-the other "remains without solution" $(2005,398)$.

To love the other as a freedom and at the same time remain a free being, is not achievable with Sartre's framework because one cannot love another without falling into a relationship of object to subject. Although Beauvoir is certainly aware of relationships dominated by the conflict between subject and object, she still believes in the possibility of a relationship in which both consider the other as subject: "The conflict can be overcome by the free recognition of each individual in the other, each one positing both itself and the other as object and as subject in a reciprocal movement" (TSS 159/LDS I:232). This is what authentic love requires. Within the framework of Beauvoir's ethics, authentic love exists when both have achieved moral freedom, while in Sartre's Being and Nothingness only inauthentic love is possible. 
To explain the differences between Beauvoir's and Sartre's respective views on romantic love, we need to look at their different ontologies. Sartre's ontology is pessimistic in its view of human relationships. Others are essentially hostile and antagonistic, a threat to my freedom. Unlike Sartre, Beauvoir does not believe our relationships are always antagonistic. Nor does she believe that being with others necessarily has to be a struggle between two minds, each seeking to dominate the other. For Beauvoir, a human being is present in the world as a being connected with others. In her own words: "I concern others and they concern me. There we have an irreducible truth. The me-others relationship is as indissoluble as the subject-object relationship" (Beauvoir 1976, 72). In addition to not seeing being-inthe-world as a fundamentally antagonistic state vis-à-vis others, Beauvoir does not understand individual humans as separate from others' being-in-the world. For Beauvoir, being is my-and-your-being-in the world, it is our being-in-the-world - it is being-with (Mitsein) (TSS 17/LDS I:32). Where Sartre's ontology is individualistic, Beauvoir's is relational (Pettersen 2008; 2010).

Another relevant difference between Beauvoir and Sartre is the fact that Beauvoir emphasizes the ambiguity of the human condition far more than he does. For Beauvoir it is both-and, not either-or. As a result, she does not dichotomize to the same extent as Sartre (Bergoffen 1999). Sartre's dichotomous approach in his analysis of our perceptions of others - as either subject or object, unfree or free (at the cost of an other's freedom) - does not leave much room for harmonious relationships in which the lovers can acknowledge each other's freedom. In Beauvoir's ontology, humans are both mind and body, both entirely free and restricted, both separate and interdependent. For her, bad faith is the result of ignoring, denying, masking, and resisting ambiguity. By accepting ambiguity, we can capture the complexity of human interaction, and avoid the problem that occurs in Sartre's philosophy that makes it impossible to establish a subject-subject relationship. Beauvoir's approach to 
our-being-in-the-world, anchored in ambiguity and intersubjectivity, departs from the dichotomous and individualistic ontology of many traditional philosophers - including existentialist philosophers such as Sartre, Kierkegaard, and Camus (Pettersen 2008; 2010). Beauvoir's ontology is what opens up the prospect of authentic love in her philosophy, a possibility she consistently defends throughout her entire output. Additionally, her unique ontology and her understanding of authentic interaction also foreshadow tenets in contemporary feminist philosophy.

\section{Relational Autonomy}

Acknowledgement of one's own and the other's freedom and otherness, which Beauvoir asserts is mandatory to authentic love, is closely related to having autonomy or being autonomous. When Beauvoir describes the interaction in authentic love relationships, she is actually portraying people with autonomy. They have their own reasons, their self-defined goals, and they are both responsible for their own decisions and actions.

However, it has been regarded as one of the many paradoxes of love that the lovers are strongly motivated to form and constitute a "we," while they also desire to remain autonomous - an antagonism Beauvoir describes both in Diary and The Second Sex. In her depictions of authentic love Beauvoir, nevertheless (and contrary to Sartre) surpasses this supposed antagonism between self-determination and cooperation, between independence and attachment when she describes a romantic relationship in which the parties manage to establish a "we" - without losing their individuality or erasing the boundaries between their two selves. In this sense, she rejects the view that a complete union must be the goal or is the nature of true love, and also the view that we are destined to remain solitary and isolated if we do not want to be dominated or dominating. 
According to Beauvoir, although couples in an authentic love relationship do not merge into complete union, obliterating their separate ego-boundaries, they can still form a "we." There are, indeed, significant differences between the "we" constituted in authentic and inauthentic relationships. In an authentic relationship, says Beauvoir, the couple should not be considered as a unit, or "a closed cell," but instead as free individuals capable also of participating in society and forming relationship with other free persons. And, she continues:

This balanced couple is not a utopia; such couples exist, sometimes even within marriage, most often outside of it: some are united by a great sexual love that leaves them free in their friendships and occupation, others are linked by a friendship that does not hamper their sexual freedom, more rarely there are still others who are both lovers and friends but without seeking in each other their exclusive reason for living. (TSS 520/LDS II:286)

The differences between the two types of "we" are worth exploring, as they shed light on an interesting understanding of autonomy in Beauvoir's philosophy. The authentic "we" is not understood as if joined by a mysterious, natural, divine or conventional intervention; external forces do not bind them. What constitutes an authentic "we" is the voluntary decision of the two to set common goals, create values and share some experiences together. This consensus forms an autonomous "we."

However, as autonomy has traditionally been understood in terms of separation, noninterference, and self-determination, the concept does not grasp such shared agency. Beauvoir's authentic love includes reciprocity, discussion, connectedness, and collaboration. Therefore, it represents a challenge to the traditional concept of autonomy. Under the traditional view of autonomy, one of the persons in an inauthentic relationship, usually the woman, has to give up his or her autonomy in order to constitute a "we," while both individuals in an authentic relationship have to abandon their autonomy to become a "we" in which they are equal. Given this perspective on autonomy, the woman who wants to live an autonomous life would seem obliged to give up any idea of being in a heterosexual 
relationship, while the man will only keep his autonomy in an inauthentic relationship. What is needed is a new concept of autonomy with space for the type of reciprocity and connectedness that we find in authentic love relationships - but without forfeiting selfdetermination or freedom.

As Beauvoir is not willing to choose between individual self-determination and the possibility of authentic love, we find what is needed to reconceptualize autonomy in her version of authentic love. Beauvoir gives us an alternative understanding of autonomy because the self she portrays as capable of authentic love is both separate and relational, with the capacity to cooperate and to self-legislate. It is not a self that dominates others, nor does it allow itself be dominated or torn apart. Based on such selves, the "we" formed in authentic love is a democratic relationship in the sense that it is freely chosen and maintained by equals, with the capacity and space for genuine, open and mutual consultation, debate, and (dis)agreement (Westlund 2005, 30).

Not only is the ability to enter into such a relation a precondition for forming and maintaining the kind of relationship Beauvoir portrays as an authentic love relationship. We can also read her understanding of authentic love as a forerunner of feminist philosophy's remodeling of the traditional concept of autonomy, which proceeded from what is termed an “individual" understanding to a "relational" understanding. Beauvoir's authentic relationship is based on "comradeship;" it is not "parasitic.” Authentic love "presupposes friendship;" hence it "may be platonic as well as sexual," she admits. Still, physical love is commonly a significant part of authentic love, as it is often what gives the "beloved its matchless value" and what maintains "their mutual magic" (Beauvoir 2015a, 78-9).

In the view of feminist ethicists such as Marilyn Friedmann (2005), Sarah Hoagland (1988), Virginia Held (1993), and Eva Kittay (1999), relational autonomy incorporates, in accordance with Beauvoir's way of doing philosophy, the lived experience of relationships. 
Based on many people's everyday experiences, it is precisely through interacting with others that one learns how to make decisions. In relationships, one discusses who will make certain decisions, and from time to time the parties freely agree to let one or the other do so. This is done without undermining either party's autonomy, or curbing their freedom. In fact, their cooperation might strengthen each individual's autonomy (Held 1993, 55). Based on an agreement, a joint autonomy is possible. This reconceptualized notion of autonomy is indeed very different from the traditional notion that privileges non-intervention and self-sufficiency.

Not only does Beauvoir challenge the traditional philosophical conception of love and autonomy, she lays the foundations for the development of a new concept of autonomy within contemporary feminist philosophy. In her analysis of the two different kinds of love she suggests how it is possible to enter into a genuine love relationship in which we get to retain our autonomous lives, while enjoying shared and vibrant lives together. For love to be experienced in this manner, both sexes must forfeit the patriarchal view of gender and love. For authentic love to be possible, both women and men must unconditionally acknowledge themselves and their partner as unique and equal, and - it goes without saying - they must act accordingly. The friendship, generosity and love achieved by such mutual recognition of freedoms are, according to Beauvoir, undoubtedly humans' highest accomplishment (TSS 159-60/LDS I:232). What is attained is not only an authentically moral attitude, as well as comradeship and the "miracle" of love $(2015 \mathrm{a}, 77)$, but also the revelation of "a new world" (2015b, 100). 


\section{Notes}

1 Beauvoir also uses literature to explore the traditional gender differences with regard to love. In her novel The Mandarins (1954), for example, she lets the relationship between Paula and Henri epitomize gendered, inauthentic love. Paula has given up her own career as a singer to devote herself completely to her husband Henri - the founder and editor of a newspaper. Paula's existence and identity are defined and dependent on her relationship with Henri. When he leaves her, Paula contemplates suicide. Beauvoir considers the consequences of inauthentic love also in other works, such as She Came to Stay (1943), and The Woman Destroyed (1967).

2 Women's inauthentic love as described in The Second Sex resembles several of Beauvoir's portrayal of the possible inauthentic existences in The Ethic of Ambiguity (1947), such as the "sub-man", the "serious man" and the "passionate man".

3 In addition, women conforming with traditional gendered expectations are also rewarded economically, metaphysically, and socially (Beauvoir 2011, 10).

4 It should be mentioned that Sartre appends a footnote in which he says: "These considerations do not exclude the possibility of an ethics of deliverance and salvation. But this can be achieved only after a radical conversation which we cannot discuss here" (2011, 434, fn. 13). I nevertheless relate to what is possible based on Being and Nothingness. 


\section{References}

Bauer, Nancy. 2001. Simone de Beauvoir, Philosophy, \& Feminism. New York: Columbia University Press, 2001.

Beauvoir, Simone de. 1947. Pour une morale de l'ambiguité. Paris: Gallimard.

Translated as The Ethics of Ambiguity. 1976. Bernard Frechtman, translator. New York: Citadel Press.

—. 1949. Le Deuxième sexe. Paris: Gallimard. Translated as The Second Sex. 2011.

Constance Borde and Sheila Malovany-Chevallier, translators. New York: Vintage Books.

—. 2004. "Pyrrhus and Cineas." In Philosophical Writings, edited by Margaret A. Simons, Marybeth Timmermann and Mary Beth Mader, 77-150. Urbana: University of Illinois Press.

—. 2015a. "It's About Time Women Put a New face on Love." In Feminist Writings, edited by Margaret A. Simons and Marybeth Timmermann, 76-80. Urbana: University of Illinois Press.

—.2015b. "What Love is - and Isn't." In Feminist Writings, edited by Margaret A. Simons and Marybeth Timmermann, 99-102. Urbana: University of Illinois Press.

Bergoffen, Debra B. 1999. "Simone de Beauvoir and Jean-Paul Sartre: Woman, Man and The Desire to be God," in Labyrinth 1(1). http://phaidon.philo.at/ iaf/Labyrinth/Bergoffen.html.

Deutsch, Helene. 1946. The Psychology of Women: A Psychoanalytic Interpretation, vol. 2. New York: Grune and Stratton.

Freud, Sigmund. 1995 [1924]. “The Economic Problem of Masochism.” In Essential Papers on Masochism, edited by Margaret Ann Fitzpatrick Hanly, 274-85. New York: New York University Press. 
Friedman, Marilyn. 2005. “Autonomy, Social Disruption, and Women.” In Feminist Theory: A Philosophical Anthology, edited by Anne E. Cudd and Robin O. Andreasen, 33951. Malden, MA: Blackwell Publishing.

Gunnarsson, Lena. 2013. On the Ontology of Love, Sexuality and Power. Toward a FeministRealist Depth Approach. Örebro: Örebro University.

Held, Virginia. 1993. Feminist Morality. Transforming Culture, Society and Politics. Chicago: The University of Chicago Press.

Hoagland, Sarah Lucia. 1988. Lesbian Ethics. Toward New Value, Palo Alto: California Institute of Lesbian Studies.

Kittay, Eva Feder. 1999. Love's Labor. Essay on Women, Equality, and Dependency, New York and London: Routledge.

Munday, Leo. 2015. “The Question of Men in Love: A Beauvoirian Response to Jørgen Lorentzen.” Nora - Nordic Journal of Feminist and Gender Research 23(3): 187202.

Schopenhauer, Arthur. 1851. On Women.

http://www.theabsolute.net/misogyny/onwomen.html

Sartre, Jean-Paul. 2005. Being and Nothingness. London and New York: Routledge Classics. Pettersen, Tove. 2007. "Freedom and Feminism in Simone de Beauvoir's Philosophy.” In Simone de Beauvoir Studies, Vol. 24, 2007-2008, edited by Yolanda Patterson, 5765. Menlo Park California: ISSN 1063.

—. 2008. "La joie existentielle et l'angoisse dans la philosophie morale de Simone de Beauvoir." [Joy and Anguish in Simone de Beauvoir's Moral Philosophy]. In (Re)découvrir l'œuvre de Simone de Beauvoir Du Deuxième Sexe à La cérémonie des adieux $[(\mathrm{Re})$ discovering the Work of Simone de Beauvoir through The Second Sex and $A$ Farewell to Sartre], edited by Julia Kristeva, 212-25. Paris: Le Bord de L'eau. 
—. 2010. "Acting for Others: Moral Ontology in Beauvoir's Pyrrhus and Cineas.” In Simone de Beauvoir Studies Vol. 26, 2009-2010, edited by Yolanda Patterson, 18-27. Menlo Park California: ISSN 1063-2042.

—. 2015. "Existential Humanism and Moral Freedom." In Simone de Beauvoir - a Humanist Thinker, edited by Tove Pettersen and Annlaug Bjørsnøs, 69-91. Amsterdam/New York: Brill/Rodopi.

Westlund, Andrea. 2009. “Deciding Together.” Philosopher's Imprint 9(10): 1-17. 